\title{
DECONSTRUCTION OF A FACEBOOK CAMPAIGN MODEL ON THE EXAMPLE OF THREE BRANDS
}

\section{DEKONSTRUKCIJA MODELA FACEBOOK KAMPANJE NA PRIM- JERU TRI ROBNE MARKE ILI BRENDA}

\author{
Vlasta Kučiš ${ }^{1}$, Slobodan Hadžić ${ }^{2}$ Darja Kupinić Guščićs \\ Faculty of Arts, University of Maribor, Maribor, Slovenia ${ }^{1}$; PressCut, Zagreb, Croatia ${ }^{2}$; MediaNet, Zagreb, Croatia ${ }^{3}$ \\ Filozofski fakultet, Sveučilište u Mariboru, Maribor, Slovenija ${ }^{1}$; PressCut, Zagreb, Hrvatska²; MediaNet, Zagreb, Hrvatska
}

\section{Abstract}

The authors of this paper present the results of desk research and content analysis of Facebook campaigns run by commercial brands. Every brand aims to increase fan activity on its Facebook page, consisting of likes, comments and shares. The authors focuse primarily on analysing the form and the content of Facebook posts and their impact on user activity. Based on their study of Facebook profiles and communication on the example of three commercial brands (a beer, a bank and women's stockings), the authors built a matrix they believe is applicable to most commercial brands and can be used as the framework for the analysis of any Facebook campaign, with minor additions and adaptations.

\section{Introduction}

User numbers are not a suitable argument for the study of the significance of social networks in the age of global digital transformation, since these numbers change daily. The internet and social networks have become an almost omnipresent part of everyday life.

Ten and more years ago, the methods for the study of social networks have become multiand interdisciplinary. Large databases of users, deploying complex algorithms to study their behaviours and preferences, form the backdrop of the internet and social networks. The research efforts are focused on identifying users' "behaviour patterns". Psychometric user tests

\section{Sažetak}

U ovom radu autori iznose rezultate desk istraživanja i sadržajne analize Facebook kampanje komercijalnih brandova. Cilj svakog branda je povećati aktivnost fanova na svojim stranicama, putem izražavanja sviđanja, komentiranja ili dijeljenja sadržaja. Autori su svoju pažnju usmjerili prvenstveno na formalne i sadržajne karakteristike objave i promatrali kako iste utječu na aktivnost korisnika. Temeljem proučavanja Facebook profila i komunikacije na primjeru 3 komercijalna branda (pive, banke i ženskih čarapa) autori su konstruirali matricu za koju smatraju da je primjenjiva na većinu komercijalnih brandova, odnosno da može biti okvir za analizu bilo koje Facebook kampanje uz odgovarajuće nadopune i manje preinake.

use emotion theories on large databases to allow precise targeting and adaptation of message contents to personality traits. Cambridge Analytica and the US presidential elections are the best example of this, along with numerous scientific papers about the big 5 and behaviour patterns. Neural science attainments are used in computer sciences at increasing speed, because the way the brain receives and reacts to auditive, visual, hearing and other stimulants, combined with the emotion theory (hope, fear, joy etc), provides the answers to the questions how important individual variables are for the development of complex consumer/user behaviour algorithms. 
"In a world abounding in information, the wealth of information means a shortage of something else: the shortage of what the information has exhausted. It is rather obvious what information exhausts: it exhausts the recipient's attention. The wealth of information therefore results in a deficit of attention and the need to efficiently allocate this attention among the abundance of information sources available for consumption" /1/. This Greenberg's thought about the attention economy from 1971 is especially applicable to social networks today. The relationship of form and content in the conditions of abundance of information is crucial for any information manager. The form precedes the content. If the form has not captured attention, there is no subsequent sequence of perception, attention and memorizing. " $80 \%$ of the world's internet users have at least one smartphone. A mobile video is a particularly promising form of communication with consumers.

"While Twitter can cause strong addiction in beginners, it is not user-friendly enough for real rookies... Instagram, on the other hand, is a fun and very well-made application that encourages people to connect via their smartphones"... $/ 2 /$.

"When we care, we share" /3/.

Attention can be defined as "focused mental engagement on a particular item of information" $/ 4 /$.

Trusov, Bucklin and Pauwels /5/ found that a word-of-mouth referral from family, friends and other online stakeholders strongly influenced the attraction of new clients. Subsequent research tried to identify the extent to which referrals increased the sales of individual product categories (cars, cosmetics etc), but results were contradictory. However, the effects of this method of receiving information about a brand last longer than the effects of classic marketing strategies. The creation of a brand page, where $\mathrm{u}-$ sers can comment on contents and like or share the brand's posts with their Facebook friends, is the main form of marketing on Facebook. Bagozzi and Dholakia /6/ argue that consumers who become fans of a brand page usually exhibit more brand loyalty and dedication and are more prepared to receive information about the brand. Furthermore, brand fans make more visits to the brand's stores, generate more positive word-of-mouth referrals, and have stronger emotional ties with the brand than persons who are not fans of the brand on Facebook /7/. According to Kang, Tang and Fiore /8/, persons who become brand fans on Facebook are motivated by meeting their social, psychological and hedonist needs. Meeting these needs leads to active participation in the brand's page (liking, commenting, sharing), which results in increased trust in the brand and finally in brand dedication. It is important to underline that people do not become brand fans because of advertising, but because they like the company's product $/ \mathbf{9 /}$. The company's marketing is crucial for keeping up the fans' impressions and encouraging the fans to spread positive information about the brand through their social network activity. However, if Facebook marketing is not approached adequately, it can even lead to loss of clients and decline in profit. Researchers therefore tried to identify factors crucial for adequate marketing on Facebook.

Every brand aims to increase fan activity on its Facebook page consisting of likes, comments and shares. The authors focused primarily on the characteristics of Facebook posts that impact user activity. Liveliness and interactivity have proven to be the key elements and they therefore require a more thorough explanation. Media liveliness can be defined as the degree to which a certain medium can reproduce the information delivered using this medium. For example, a phone call is less lively than a video, because it is impossible to reproduce non-verbal communication aspects present in a video in a phone call. The definition is derived from the Media Richness Theory by Richard L. Daft and Robert H. Lengel (1984). Starting from the postulates of the Contingency Theory and the Information Processing Theory, Daft and Lengel underline that, the more ambiguous and uncertain a task is, the livelier the medium used needs to be. Steuer /10/ defines liveliness as the degree to which a certain medium, in this case a 
48

Facebook post, stimulates different senses. Liveliness can therefore be increased by including animations and using more colours or images. According to this definition, a video is livelier than a photo, because it stimulates hearing in addition to vision /10/. Existing studies of content liveliness argue that the intent to click on a content and the actual click rate are proportional to liveliness $/ \mathbf{1 0} /$. It also seems that higher degrees of liveliness are most efficient in increasing a positive attitude toward a website /11/, as cited in $/ \mathbf{1 0} /$.

In addition to media liveliness, the degree of interactivity a post requires from a user is also crucial. Brand posts differ by their degree of interactivity. A textual status is considered noninteractive, while a link is much more interactive because it requires a certain activity from the user. Asking a question that the user is expected to answer is considered the highest degree of interactivity. The findings of past studies are inconclusive. Some authors believe that the connection between the interactivity of contents and a positive attitude toward a brand is linear $/ \mathbf{1 0} /$, while others advocate an inverted U-relationship, underlining that there is an optimal level of interactivity, after which the attitude again becomes more negative $/ \mathbf{1 1} /$, as cited in $/ \mathbf{1 0} /$.

Researchers soon wondered if there was a relationship between liveliness and interactivity. De Vries, Gensler and Leeflang /10/ studied the impact of brand post characteristics (visual liveliness and interactivity), post contents (degree of informativeness vs. entertainment), the post's position on the brand's page, and the valence of other fans' comments on the popularity of a post, defined in terms of the number of likes and comments. They examined the time when the posts were published, the length of the posts, and the category of the advertised products. They found that lively and moderately interactive posts, such as videos of giveaways, increased the probability that the post would receive likes. If the content is too interactive, such as a question that requires an answer from the user, the likelihood of receiving likes is decreased. However, such contents expectedly in- crease the number of comments. The other characteristics of the post have no impact on the number of comments. Entertainment contents also decrease the likelihood of receiving likes, because fans expect the brand to provide information about the product rather than entertainment. Pletikosa Cvijikj and Michahelles /12/ discussed similar issues. They wanted to know what kind of contents resulted in more fan engagement and when posts should be published in order to encourage reactions. They divided posts according to content type (informative, entertainment, giveaways), media type (status, photo, video or link, depending on the degree of liveliness and interactivity of media contents), and the time of the post. Their results are opposite to those obtained by De Vries, Gensler and Leeflang $/ \mathbf{1 0} /$. The results obtained by Pletikosa Cvijikj and Michahelle /12/ point to the conclusion that entertainment content results in greatest fan engagement. Interestingly, photos defined by low interactivity and low liveliness generated the most fan activity. A similar result was obtained for statuses characterised by low interactivity and zero liveliness. These authors therefore argue that the degree of interactivity is in a negative correlation with the likelihood of receiving likes. They underline the importance of differentiating between the types of activities on Facebook used as criteria (likes, shares, comments), because the patterns of predictor variables for the criteria are somewhat different.

An increasing number of companies are investing efforts in understanding the effect of their activities on social media, i.e. the (financial) efficacy of using this method to promote their products and services. The organic reach strategy is a way to maximize visibility on Facebook (or other social media) without paying for advertising. The number of likes a post or a page receive is also one of the important factors impacting the success of the reach and visibility of products and services $/ \mathbf{1 3} /$.

Organic reach on Facebook has declined considerably in recent years /14/: to be more precise, it declined from 16\% in 2012 to $6 \%$ in 2014 /15/. When we talk about organic reach, we are referring to the total number of unique individuals viewing the brand's pages and posts via unpaid 
distribution. This is the opposite of paid reach, which is defined as the number of unique individuals exposed to posts resulting from paid advertisements ("What's the difference between paid and total reach?", 2017). Kite/16/ et al. state that paid advertisements are important because they have a wider reach (reaching users who do not necessarily follow the pages of the brands publishing the ads), but that it is also important to increase organic reach, because it reflects greater personal and subjective engagement (especially when combined with likes, shares and comments), which is also crucial for total marketing. A substantial decline in organic reach is explained by the sudden increase in the number of active users and increased brand activity, which generates more mutually competitive content $/ \mathbf{1 5} /$ )that individually cannot achieve the same width of reach anymore $/ \mathbf{1 4} /, / \mathbf{1 7} /$. It is more difficult for posts to achieve a wide reach today due to algorithm changes on Facebook and other social networks, which favour paid reach over organic reach /18/, /19/. Facebook also uses an algorithm to filter posts appearing on the users' walls, because users would otherwise be exposed to too many posts and would not have the time to view them all. This algorithm takes into consideration factors such as the users' interest in the content, the type of post, and how current it is $/ 20 /$. This causes the reach of individual posts to decline, because the number of users exposed to them declines. In addition, organic reach is very difficult and challenging to measure. This is not the case with paid reach, as social media can identify all consumers who have been exposed to paid posts /18/). Kanuri et al. /21/ compared social media measurement data pertaining to the organic reach of posts and the number of likes. In this context, organic reach referred to the total number of unique social media users who viewed posts for free on their walls. Maintaining a strong base of such viewers can increase brand visibility and attractiveness /22/; /23/. However, due to the aforementioned increased competition in post visibility (a result of the substantial increase in their number, which makes some of them outdate very quickly and fall to the bottom of the post wall), companies that use social media in their promotion face a constant decline in organic reach /24/. Unlike organic reach, pressing the "Like" button is an active and intentional action on the users' part that reflects their preferences $/ 21 /$, and we can argue that post likes contribute more to marketing success than organic reach. An increase in the number of likes and comments results in the post being shown to more users, which increases its reach /25/. Liking a brand's page is considered active approval of the brand in question, which also encourages increased brand trust in other users /26/.

The idea of the change in Facebook's algorithm that went into effect in early 2018 was to show to the users posts about things that they wanted to see and to keep them on the platform longer. Posts that are shown on users' walls are thus related to the links that the users share in their messages, comments, likes, replies and important interactions. This algorithm change has influenced how the reach of posts is measured. Every time a user logs in, approximately 250 posts are loaded on their walls. Earlier, all of these posts were considered reach, even if the user has not viewed them. Now, only the posts that appeared in the timeline and posts that a person has viewed are considered reach. For example, the company Kuno Creative mentions that, according to the new algorithm, their most popular post in June 2018 - an ordinary photo of one of their employees - reached 291 users, and it generated only four likes. The company's page has as many as 7,968 follower $/ 27 /$.

In 2016, Facebook announced that brand pages would become more dependent on the sharing of users' posts, i.e. that their organic reach would depend on the number of shares. This has made Facebook post sharing an important part of marketing for some companies /28/; /29/. Organic reach of brands' posts allows more efficient paid advertising on Facebook. For example, the use of photos and updates has proven to generate the most user likes /30/. Paid ads therefore must adapt to such user affinities in order to achieve a greater impact. This means that efforts to increase the number of likes, shares and comments of individual posts are an integral part of achieving a satisfactory organic reach, which is in turn an integral part of satisfactory marketing success. Finally, it is worth mentioning that 
there are modern marketing tactics, so-called influencer marketing, which promote informal arrangements with celebrities and influential persons who promote individual brands through their work /31/;/32/; /33/, /34/, thus contributing to increased organic reach.

A review of the available reference works about this topic leads us to the conclusion that the factors influencing fan activity with regard to brand posts on Facebook have not been sufficiently researched. Available results are also contradictory, necessitating further research.

Any communication, in its simplified form, consists of a sender and their intention, the content of the message, adapted to the characteristics of the recipient in terms of form and shape, and the recipient of the message and the evaluation of their response.

In this paper, we focused on defining a matrix that could be used for the deconstruction and content analysis of commercial brands' Facebook campaigns. The idea is to make the matrix variables used in content analysis, with possible minor adaptations and additions, applicable to all or most other Facebook communications campaigns used by commercial companies to promote their brands and to communicate with their consumers.

\section{Methodology}

We used the data about the posts published on Facebook (FB) profiles of three entities (brands), Ožujsko pivo (beer), Erste banka (bank) and Jadran čarape (stockings) over a period of three months, from 1 March to 31 May 2019.

We analysed the elements of form and content in order to identify how the brands communicate with their target audience on Facebook and which audiences they address. In the period in question, we analysed 64 posts by Erste banka, 36 Facebook posts by Ožujsko pivo and $25 \mathrm{Fa}-$ cebook posts by Jadran čarape, published on their respective FB profiles.

The analysis of Erste banka's posts did not include posts containing information published by their customer service with warnings about unauthorized access to their clients' credit cards and calls for caution in the use of credit cards and in replying to emails asking recipients to disclose their personal information. These posts are not of marketing of PR campaign nature and were therefore left out of the analysis.

In our choice of the subjects whose FB profiles we would analyse, we were guided by the intent to choose established commercial brands that already have their consumers and their profiled target groups, as well as the criterion of having their own, active FB profiles with a community of followers that the brands are trying to encourage to be more engaged with their communications. We chose a producer, distributor and seller of beer, a product traditionally designed for the male population; a company offering banking and financial services; and a producer and seller of women's lingerie and stockings.

\section{The problem and the objective of the research}

The objective of this paper was to define a matrix that could be used for the deconstruction and content analysis of commercial brands' Facebook campaigns.

\section{Hypotheses:}

H1: Brand promotion campaigns on Facebook are focused in two directions: communicating the quality and the characteristics of the brand to the target audience, and maximizing their reach and influence by being as viral as possible.

H2: An analysis of the form and content of Facebook posts can lead to conclusions about the audience that the campaign is addressing and the messages it is trying to communicate.

A single post on the FB profiles of analysed subjects in the period between 1 March and 31 May 2019 was the unit of analysis.

The matrix, as the basic tool for qualitative content analysis, contains the following elements: Form elements are:

- Post title

- Post text

- Image/photo

- Video

- Other forms (drawings, graphs, surveys, maps, diagrams, cartoons and animations, caricatures, etc).

Coden: IORME7 
Almost all posts analysed for the purposes of this paper contained some form of visualisation, usually photos or videos.

We therefore focused on a qualitative analysis of the content of the posts in this paper and chose to neglect the influence of form elements.
Content elements were classified into 12 categories and 43 subcategories. In the categorisation of each post (analysis unit), all content elements (category and subcategory) applicable to the post were associated with it.

\section{Categories (Group) Subcategories (basic content elements)}

Science

Arts

Lifestyle

Lifestyle

Nature

Nature

Call

Call

Call

Persons

Persons

Persons

Persons

Persons

Persons

Persons

Persons

Persons

Persons

Persons

Persons

Persons

Persons

General

General

Media

Food

Economy

Economy

Economy

Economy

Event

Brand

Brand

Brand

Brand

Brand
The post discusses scientific achievements

The post discusses exhibitions, concerts, architecture, works of art, books, theatre shows...

The post advocates a healthy, active lifestyle

The post advocates a laid-back, carefree, eccentric lifestyle

The post presents nature and its beauties

The post discusses ecology and environmental protection

The title/text of the post contains a question or call for engagement

The post is about a giveaway

The post is about a survey

The post contains an image of an infant or animal

The post contains an image of attractive person(s)

The post contains an image or a video featuring celebrities

The post contains an image or a video featuring ordinary people

The post promotes a particular lifestyle

The post shows an entertaining, funny or humorous situation

The post shows persons engaged in a sports/recreation activity

The post shows clumsy, lazy persons, excessive eaters or drinkers...

The post shows persons who are learning something

The post is about independence

The post is about human rights and equality

The post promotes family values

The post shows persons playing

The post addresses children

The post marks an important date or reminds about a past event

The post is written in a foreign language

The post contains links to contents from other media

The post contains a photo or video of food or people eating

The post discusses economic successes associated with the brand

The post discusses economic successes associated with other subjects

The post discusses finance, spending, shopping

The post offers the possibility of employment or earnings

The post announces, describes or documents an event

The post contains an image/photo/video/logo of the brand

The post contains elements associated with the brand, not including an image, logo or name of the brand (e.g. it contains colours, sounds or shapes reminiscent of the brand), including the image of a product, but without a logo

The post promotes a new product or service

The post is an ad copied from another medium

The post contains an image of the brand mascot 
Brand

Brand

Brand

Brand

Brand
The post promotes another product/brand

The post directly encourages consumption of the product/service

The post is reminiscent of famous movies, TV series, music etc

The post is related to a humanitarian activity

The post includes an image of a store, showroom etc

\section{Research and analysis results}

We will discuss the results for the three analysed entities individually and compare the features that their campaigns have in common and the features that set them apart in order to try and answer the questions asked in the objectives of this paper.

\section{Ožujsko pivo}

In June 2019, when this paper was written, the FB profile of Ožujsko pivo (Žuja) had a cover photo showing five cans of Ožujsko pivo beer featuring the drawings of endangered and protected species in Croatia (lynx, wolf, dolphin and griffon vulture). The photo also contained two messages, one informing the reader that 0.5 HRK was donated for the protection of endangered species for every 0.51 of the beer, and the other, smaller and less visible, stating: "Think about it: don't drink and drive."

This seems to be sending the following message: Even though we are selling you alcohol, we are still a responsible brand dedicated to environmental protection and your safety.

A total of 36 posts were published on Ožujsko pivo's FB profile in 90 days, which translates to an average of 0.4 posts per day or one post every two and a half days. In spite of the relatively modest number of not even one post in every two days, the FB community on Ožujsko pivo's profile is impressive both in terms of numbers and activity. We recorded a total of 13,849 comments in 90 days, or an average of 384.7 comments per post; 32,179 likes, or an average of 893.9 likes per post; and 1,195 shares, or an average of 33.2 shares per post. This indicates that the community Žuja is addressing consists of passionate beer lovers, but also persons whose lifestyle includes socializing over beer and food, supporting their favourite sports teams at matches or in front of the TV, and a strong bond with their family and friends, all with a hefty dose of fun and laughter.

Two posts are absolute recorders in terms of the number of comments and likes. One was a funny International Women's Day survey posted on 8 March, which generated 3495 comments, 3658 likes and 97 shares, and the other was an April Fools' Day joke, published on $1 \mathrm{~A}-$ pril, with the following text: "Presenting chewing gums with Žuja flavour. True Žuja lovers will understand!" This post generated 3209 comments, 4563 likes and 187 shares.

It is also worth mentioning that Ožujsko pivo's FB community has 340,111 "friends", persons who liked the FB page, an impressive number for Croatian circumstances.

We analysed all 36 posts published in the period between 1 March and 31 May 2019.

The table below shows the most common matrix elements on Žuja's profile:

\begin{tabular}{|l|l|r|r|}
\hline Group & Content elements & ŽUJA & \% ŽUJA \\
\hline Brand & The post contains an image/photo/video of the brand & 30 & $83.33 \%$ \\
\hline Call & The title/text of the post contains a question calling for engagement & 14 & $38.89 \%$ \\
\hline Brand & The post promotes a new product or service & 8 & $22.22 \%$ \\
\hline General & The post marks an important date or reminds about a past event & 7 & $19.44 \%$ \\
\hline Call & The post is about a giveaway & 6 & $16.67 \%$ \\
\hline
\end{tabular}




\begin{tabular}{|c|c|c|c|}
\hline Persons & The post contains an image or a video featuring celebrities & 6 & $16.67 \%$ \\
\hline Persons & The post shows an entertaining, funny or humorous situation & 6 & $16.67 \%$ \\
\hline Persons & The post contains an image or a video featuring ordinary people & 5 & $13.89 \%$ \\
\hline Persons & The post promotes a particular lifestyle & 5 & $13.89 \%$ \\
\hline Brand & The post promotes another product/brand & 5 & $13.89 \%$ \\
\hline Persons & The post promotes family values & 4 & $11.11 \%$ \\
\hline Food & The post contains a photo of food & 4 & $11.11 \%$ \\
\hline Lifestyle & The post advocates a laid-back, carefree, eccentric lifestyle & 3 & $8.33 \%$ \\
\hline Persons & The post shows persons engaged in a sports/recreation activity & 3 & $8.33 \%$ \\
\hline Event & The post announces, describes or documents an event & 3 & $8.33 \%$ \\
\hline Brand & The post directly encourages the consumption of the product/service & 2 & $5.56 \%$ \\
\hline Nature & The post presents nature and its beauties & 1 & $2.78 \%$ \\
\hline Call & The post is about a survey & 1 & $2.78 \%$ \\
\hline Persons & The post shows persons who are learning something & 1 & $2.78 \%$ \\
\hline Persons & The post shows persons playing & 1 & $2.78 \%$ \\
\hline Economy & The post discusses economic successes associated with the brand & 1 & $2.78 \%$ \\
\hline Brand & The post is an ad copied from another medium & 1 & $2.78 \%$ \\
\hline Brand & The post is reminiscent of famous movies, TV series, music etc & 1 & $2.78 \%$ \\
\hline
\end{tabular}

More than $83 \%$ posts contain an image or photo of the brand, usually showing a bottle of Ožujsko pivo beer, clearly showing the label and the logo. This points to strong focus on this established brand and product, usually consumed in this very form (from a beer bottle or glass). A can of Žuja is featured in the posts less frequently. Almost 39\% of the posts call for engagement in the post title or text: there is a question calling for a reply or a comment, often associated with a giveaway ( $16.7 \%$ posts), and in one case the post contained a survey.

$22 \%$ posts promote a new product, the Hoppy Lager, a lighter beer with the addition of a fruity taste.

$19 \%$ posts mark an important date such as Easter, $1^{\text {st }}$ of May (International Workers' Day), International Women's Day, Fathers' Day and Mothers' Day. This choice of important dates shows that the FB profile "Žuja je zakon", the roof slogan of Ožujsko pivo, is not only focused on the male population, but also on women, and young parents, mothers and fathers.

The posts featuring celebrities such as TV and moovie actors Rene Bitorajac, Goran Navojec and Gordan Bogdan provide an additional confirmation of the thesis that the brand's primary focus is on young fathers and their wives. The aforementioned three actors are featured in the videos in comical, clumsy and somewhat embarrassing situations that they find themselves in because they wanted to impress and entertain their children (even though the children are not shown in the videos, the implication is that they are standing in front of their funny, clumsy fathers). The same characters are also featured in adds in offline media. 
54

Other celebrities, such as Zlatko Dalić, the coach of the Croatian national football team, and Croatian footballers, as well as videos announcing football matches, are indicative of a focus on football supporters, because there is well-known, unbreakable bond between beer and supporting sports clubs.

Four posts or $11 \%$ promote family values, showing dedicated fathers and husbands devoted to their wives.

Four posts or $11 \%$ contain images of food. It is always the same type of food - roasts, potatoes, barbecue etc - calorie-rich foods that call for a glass of beer to help digest it.

Only two posts contain direct calls to consume products.

Contrary to expectations, only three posts call for a carefree, leisurely, eccentric lifestyle. Instead, they promote responsibility, care, and family values, all accompanied by the requisite glass of Žuja beer.

\section{Erste banka}

At the moment when this paper was written, the cover photo of Erste banka's profile showed a black cat whose fur is replaced with peacock feathers on the back. The background of the photo is Erste banka's corporate light blue colour, and it is accompanied by the following text: "Don't change yourself, change your bank!"; "Move your account to Erste!" and "12 months free of charge".
This kind of communication, which directly calls the reader to use the services offered by the bank, aided by an extra incentive "free of charge", is typical of Erste banka's FB and we came upon it frequently in the posts we analysed.

We analysed 65 of 71 posts published in the analysed period. From our analyses, we excluded posts dealing with information about the safety reasons why Visa cards could not be used, the warning about a fake Erste banka FB page, and similar posts addressing security in dealing with the bank and its products and services. These posts mainly generated negative comments and displeasure among the bank's users and had nothing to do with the intended communication campaign, focused on building and consolidating the brand's reputation.

Erste banka has 42,594 "friends", i.e. persons who liked its page, on its Facebook profile.

In the 90-day period, 65 posts aimed at building brand reputation were published on the FB profile, which translates to an average of 0.72 posts a day, or one post in every 1.38 days. The posts were much more frequent than Ožujsko pivo's. The posts generated 599 comments or an average of 9.2 comments per post; 16,124 likes or an average of 248.1 likes per post; and 267 shares or an average of 4.1 shares per post. We may conclude that Erste banka's FB profile community is much less active than Ožujsko pivo's.

\begin{tabular}{|l|l|r|r|}
\hline Group & Content elements & Erste & $\%$ Erste \\
\hline Persons & The post contains an image or a video featuring ordinary people & 41 & $64.06 \%$ \\
\hline Call & The title/text of the post contains a question calling for engagement & 28 & $43.75 \%$ \\
\hline Event & The post announces, describes or documents an event & 19 & $29.69 \%$ \\
\hline Persons & The post shows an entertaining, funny or humorous situation & 17 & $26.56 \%$ \\
\hline Brand & The post contains an image/photo/video of the brand & 16 & $25.00 \%$ \\
\hline Call & The post is about a giveaway & $23.44 \%$ \\
\hline Arts & $\begin{array}{l}\text { The post discusses exhibitions, concerts, architecture, works of art, books, } \\
\text { theatre shows... }\end{array}$ & 14 & $21.88 \%$ \\
\hline Brand & The post directly encourages the consumption of the product/service & 14 & $21.88 \%$ \\
\hline
\end{tabular}




\begin{tabular}{|c|c|c|c|}
\hline Lifestyle & The post advocates a healthy, active lifestyle & 9 & $14.06 \%$ \\
\hline Persons & The post shows persons engaged in a sports/recreation activity & 9 & $14.06 \%$ \\
\hline Brand & The post contains a photo of the brand mascot & 8 & $12.50 \%$ \\
\hline $\begin{array}{l}\text { Eco- } \\
\text { nomy }\end{array}$ & The post discusses finance, spending, shopping & 6 & $9.38 \%$ \\
\hline Persons & The post contains an image or a video featuring celebrities & 5 & $7.81 \%$ \\
\hline Persons & The post shows persons playing & 5 & $7.81 \%$ \\
\hline $\begin{array}{l}\text { Eco- } \\
\text { nomy }\end{array}$ & The post offers the possibility of employment or earnings & 5 & $7.81 \%$ \\
\hline Brand & The post promotes another product/brand & 5 & $7.81 \%$ \\
\hline Lifestyle & The post advocates a laid-back, carefree, eccentric lifestyle & 3 & $4.69 \%$ \\
\hline Persons & The post promotes a particular lifestyle & 3 & $4.69 \%$ \\
\hline Persons & The post shows persons who are learning something & 3 & $4.69 \%$ \\
\hline General & The post marks an important date or reminds about a past event & 3 & $4.69 \%$ \\
\hline Brand & The post promotes a new product or service & 3 & $4.69 \%$ \\
\hline Persons & The post is about independence & 2 & $3.13 \%$ \\
\hline Persons & The post is about human rights and equality & 2 & $3.13 \%$ \\
\hline Food & The post contains an image of food & 2 & $3.13 \%$ \\
\hline Nature & The post discusses ecology and environmental protection & 1 & $1.56 \%$ \\
\hline Persons & The post promotes family values & 1 & $1.56 \%$ \\
\hline Persons & The post addresses children & 1 & $1.56 \%$ \\
\hline $\begin{array}{l}\text { Eco- } \\
\text { nomy }\end{array}$ & The post discusses economic successes associated with the brand & 1 & $1.56 \%$ \\
\hline $\begin{array}{l}\text { Eco- } \\
\text { nomy }\end{array}$ & The post discusses economic successes associated with other subjects & 1 & $1.56 \%$ \\
\hline
\end{tabular}

Unlike Ožujsko pivo's FB profile, Erste banka's communications on FB rarely feature celebrities (they appear in only $7.8 \%$ of the posts), while "ordinary" people, or actors playing ordinary people, appear in $64 \%$ of the posts.

The communications suggest that Erste is a bank for ordinary people, and they are especially focused on young people who are just starting their life together, since the posts often feature images of a young man and a young woman in a fun environment, suggesting that they are celebrating moving into a new apartment, financed by a loan from Erste banka. They also underline how carefree the young couple is about financing, since the bank is there to take care of it. The same characters are also featured in adds in offline media.

In addition to showing "ordinary" people in fun or humorous situations (edited photos and videos), the bank often publishes content from everyday life, such as images from sports events and competitions (Dalmatian Handball 
56

League, Homo si teć, Blue League, Rijeka Run etc).

Almost $44 \%$ posts contain a question or some other form of call for engagement. For instance, the posts invite the readers to apply to sports events sponsored by the bank or to the young artist exhibition Erste fragmenti, or to vote for works of art in the contest. Users who comment or answer the questions often receive complimentary tickets or other rewards. For example, the announcement of the Weekend Media Festival and Erste banka's presentation called "A Glass of Finances and a Plate of Cookies" was covered with the following invitation: "Give describing your enthusiasm for the gastro culture - food, coffee, beverages, spices - your best shot, and we will reward the two most creative foodies with two three-day tickets each!“

$25 \%$ posts contain an image of Erste banka's logo, and another $12.5 \%$ contain an image of Medo Štedo, the bank's trademark and the brand mascot.

$23 \%$ posts contained a giveaway, and $22 \%$ dealt with culture or arts contents (art exhibition Erste fragmenti or theatre shows sponsored by Erste). $22 \%$ posts contained direct invitations to use the bank's services.

$14 \%$ posts called for an active and healthy lifestyle, and the same number of posts showed persons engaged in a sports or recreational activities. Five posts or $7.8 \%$ presented persons playing a game; the same percentage offered the possibility of employment, internship or earnings; the same percentage promoted another product or brand (Kaptol kino, WMF, event sponsors etc); and the same percentage featured an image or video of a celebrity (handball players Balić and Metličić).

Three posts promote a new service, the KEKS pay mobile app, which allows users to send and receive money quickly and securely free of charge. Two posts are dedicated to human rights and equality, and the same number is dedicated to independence.

One post addresses children, inviting them to become members of the Erste klub and offering the Super account package to young people, free of charge.

\section{Jadran čarape}

The cover photo on the FB profile of the Zagrebbased company Jadran čarape shows two attractive models dressed in black stockings, bras and short coats, emphasising their casual, daring and attractive looks. The company's logo is located next to the image, on the right side, along with the following text: New AW collection 18-19. With this introductory element of its FB profile, the company sends the message that it has no ambitions other than to promote its core products, women's stockings and lingerie.

The FB profile of Jadran čarape has 23,879 "friends", i.e. persons who have liked the profile.

We analysed 25 posts published in the period from 1 March to 31 May. Jadran čarape published an average of 0.27 post per day, or one post every 3.6 days.

The posts generated 173 comments or an average of 6.9 comments per post; 5,609 likes or an average of 224.4 likes per post; and 86 shares or an average of 3.4 shares per post.

\begin{tabular}{|l|l|r|r|}
\hline Group & Content elements & Jadran & \% Jadran \\
\hline Persons & The post promotes a particular lifestyle & 25 & $100.00 \%$ \\
\hline Brand & $\begin{array}{l}\text { The post contains elements associated with the brand, not inclu- } \\
\text { ding an image, logo or name of the brand (e.g. it contains colo- } \\
\text { urs, sounds or shapes reminiscent of the brand). They can in- } \\
\text { clude an image of the product (without the logo) }\end{array}$ & 24 & $96.00 \%$ \\
\hline Persons & The post contains an image of attractive person(s) & 13 & $52.00 \%$ \\
\hline
\end{tabular}




\begin{tabular}{|l|l|r|r|}
\hline Call & $\begin{array}{l}\text { The title/text of the post contains a question calling for engage- } \\
\text { ment }\end{array}$ & 9 & $36.00 \%$ \\
\hline Brand & The post contains an image/photo/video of the brand & 9 & $36.00 \%$ \\
\hline Brand & $\begin{array}{l}\text { The post directly encourages the consumption of the pro- } \\
\text { duct/service }\end{array}$ & 4 & $36.00 \%$ \\
\hline General & The post marks an important date or reminds about a past event & 3 & $16.00 \%$ \\
\hline Event & The post announces, describes or documents an event & 3 & $12.00 \%$ \\
\hline Brand & The post promotes a new product or service & 3 & $12.00 \%$ \\
\hline Brand & The post promotes another product/brand & 3 & $12.00 \%$ \\
\hline Brand & The post includes an image of a store, showroom etc & 2 & $8.00 \%$ \\
\hline Persons & The post contains an image or a video featuring ordinary people & 2 & $8.00 \%$ \\
\hline Food & The post contains a photo of food & 1 & $4.00 \%$ \\
\hline Lifestyle & The post advocates a healthy, active lifestyle & 1 & $4.00 \%$ \\
\hline Persons & The post promotes family values & $4.00 \%$ \\
\hline Brand & The post is related to a humanitarian activity & 3 & 3 \\
\hline
\end{tabular}

Our conclusion is that all posts promote the lifestyle of a fashion-conscious young woman who looks good and dresses smart and sexy, with an emphasis on stockings and lingerie. 24 out of 25 posts published between 1 March and 31 May 2019 contain an image of a product, but not necessarily the company logo (only 9 posts or $36 \%$ contain the logo). Also, $52 \%$ posts contain photos of attractive women (professional models) wearing stockings or lingerie. Even though they are not celebrities, they are not ordinary people "next door" either.

$36 \%$ posts directly call on the readers to buy the products (they contain a "buy now" button or offer special discounts and benefits to entice consumers to make a purchase).

$16 \%$ posts mark an important date, such as the World Down Syndrome Day, Easter, International Workers' Day, or International Women's
Day. Three posts each document or announce an event (e.g. BRA FITTING DAY on 28 March in Zagreb); promote a new product or service (new collection); include an image of a store; promote another brand (Gloria, Story, Zaba Mastercard etc).

\section{Similarities and differences}

The analysed FB profiles differ by quantitative elements: the number of "friends", the frequency of posting, and the number of comments, likes and shares, i.e. the engagement of their audience.

Ožujsko pivo's FB profile has the most "friends" $(340,111)$ and could therefore have been expected to have the most active FB community among the three analysed subjects. Žuja has the highest total number of comments and the highest average number of comments per post, the most likes, and the most shares. 


\section{Total and average number of comments per profile}

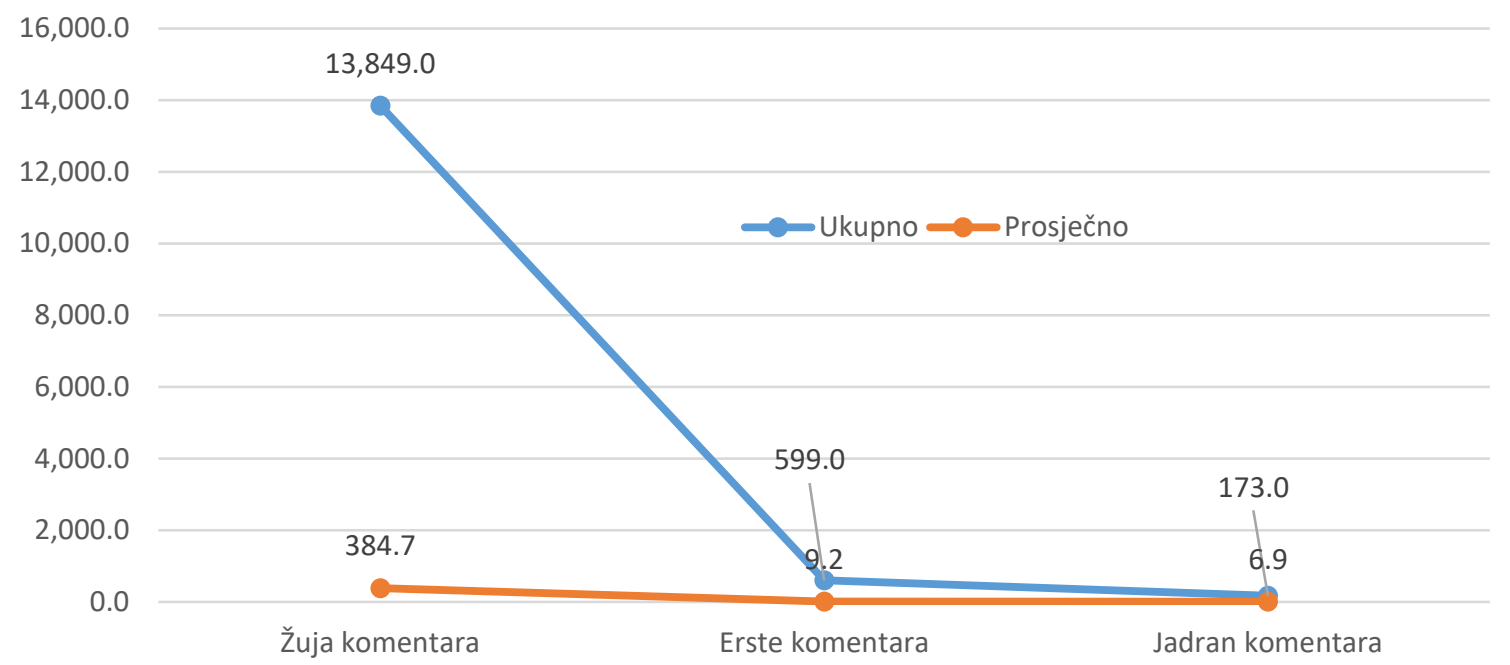

Left to right: Number of comments for Žuja, Number of comments for Erste, Number of comments for Jadran; blue $=$ total, red $=$ average

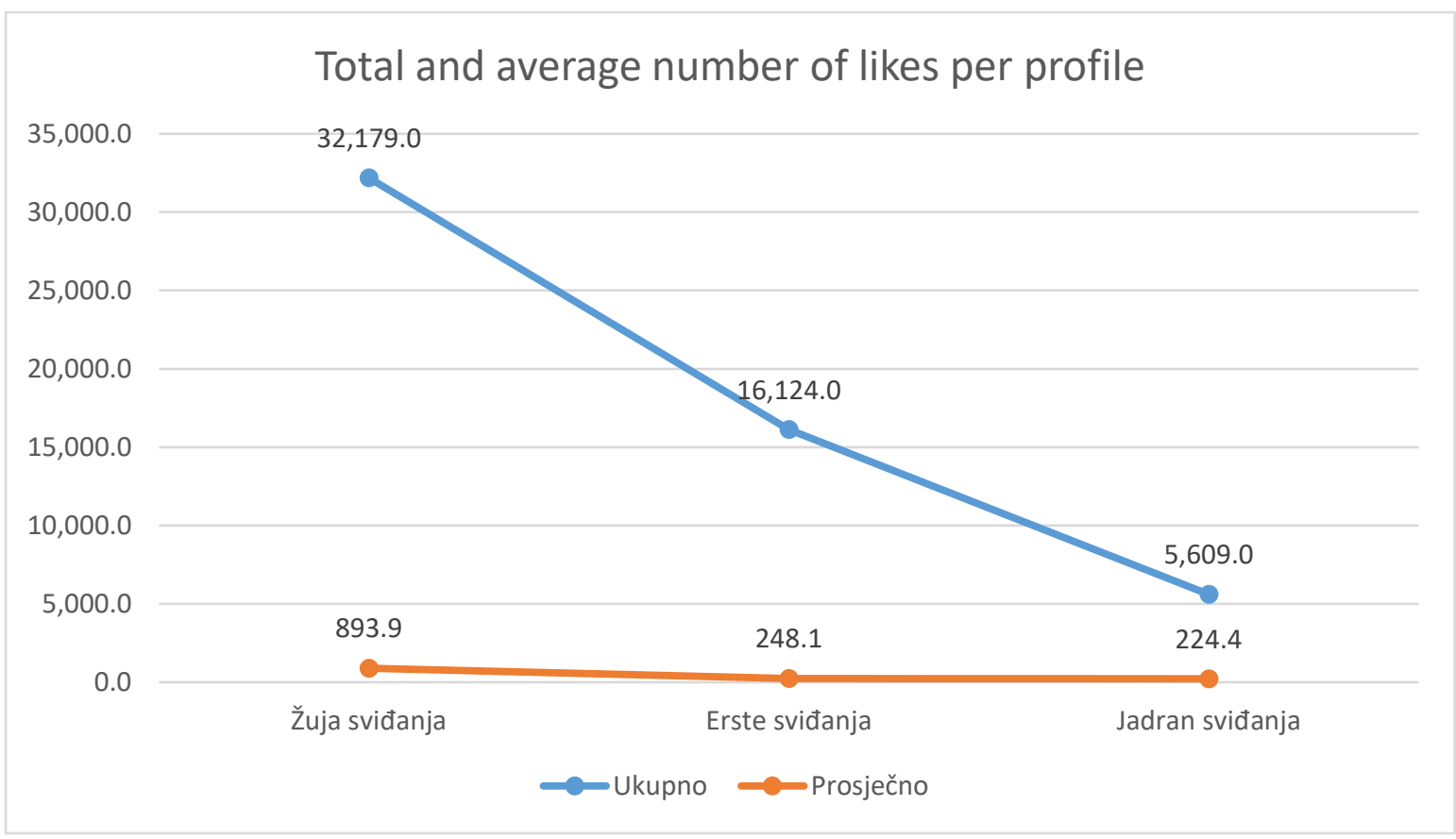

Left to right: Number of likes for Žuja, Number of likes for Erste, Number of likes for Jadran; blue = total, red $=$ average

There is a similarity between the three companies in the way they use questions or other stimuli in the titles of their posts, calling for engagement (comment, answer questions or surveys, apply to a giveaway or a game, etc). Erste ISSN 1330-0067 banks does it most often, in $44 \%$ of its posts. Žuja does it in $39 \%$ of its posts, and Jadran in $36 \%$ of its posts. The three companies all also use important dates in their posts. Zuja is the leader in this respect, having used important dates in $19.44 \%$ of its posts. Erste only used them in $4.69 \%$ of its posts, and Jadran had $16 \%$ posts dedicated to specific dates. 
All three companies use photos, images or videos of their brands, or logos (Žuja in $83 \%$ of its posts, Jadran in $36 \%$ and Erste in $25 \%)$. Jadran also uses images of its products (usually women's stockings) in $96 \%$ of its posts, and the images do not necessarily include a logo. All three companies also use partners in promoting, advertising and selling their products, albeit in different ways. Jadran most often partners with Gloria and Story magazines, which feature discount coupons for Jadran's products in their issues. In this period, Žuja partnered with Podravka and its brand Dolcella (a complimentary gift for moms with a case of beer for dads) and with Porsche, which helped transport all these cases of beer across Croatia. Erste has a number of different partners, including the Reach for Change Croatia Foundation, with whom Erste organised a financial sustainability workshop; In the Zone - Accelerator for Impact Entrepreneurs; the Weekend Media Festival; Media Com Global, 404, BBDO, and a number of projects and sports and culture events sponsored by the bank (Rijeka International Small Scene Festival, Handball League of Dalmatia, Homo si teć, the Blue League, Erste fragmenti etc).

None of the companies used photos of infants or animals in their FB campaigns in the analysed three-month period, and none published posts dedicated to scientific achievements, nor posts showing clumsy or lazy persons, or excessive eaters or drinkers. Human rights and equality were discussed in only two posts by Erste, and the same applies to independence. Family values were promoted in four posts by Ožujsko pivo and in one post by Jadran čarape and Erste banka each.

All three companies published videos directly encouraging the use of their products or services (Žuja had 5.56\% such posts, Jadran 36\%, and Erste 22\%). (Example: Your own home does not have to be an unattainable dream. With an interest rate from $2.9 \%$, start planning your housewarming party right away: erstebank.hr/d_oma.")

Ožujsko pivo has a large FB community (340,111 likes). Considering their involvement in communication on FB and their level of en- gagement, we may conclude that they are passionate beer lovers and brand fans, and no special presentation or communication of its qualities is needed in their case. Still, it is obvious that Žuja's FB profile addresses younger people, family people who like socializing, humour and lots of fun. It often mentions moms and dads and their dedication to their children, especially when dads are concerned. Žuja's FB also encourages husbands to treat their wives (moms) well.

Ožujsko pivo indirectly and subtly presents itself as a responsible corporate brand, aware of the restrictions in the promotion of its products, which nevertheless finds non-aggressive ways to encourage their consumers to drink more beer.

Erste banka directly communicates its strategy with its cover photo: attract as many other banks' customers as possible, and persuade them to move to Erste. The communication in Erste banka's posts targets a very broad audience, but primarily young people who are about to buy their first apartment, start a family, or start a business, whether it is a modern technology start-up or a farm. Erste has 42,594 "friends", eight times fewer friends than Ožujsko pivo.

Erste is also featured as the sponsor of a number of sports, recreational, educational and art events, which it covers in detail on its FB page, building the image of a responsible corporate citizen, well-versed in the trends and the context of the time and space it is operating in. In this sense, Erste promotes participation in races, sports events, exhibitions, theatre shows etc. Erste banka is very active in terms of its number of posts and their content and in communication with members of its Facebook community. Jadran čarape has only 23,879 "friends" on its FB profile, 14 times fewer friends than Ožujsko, and 1.8 times fewer friends than Erste banka. Still, this number is not so unsubstantial, considering that it is a specific product targeting only women. In 25 of the analysed posts, Jadran čarape underlines the qualities of its brand in its communications, showing women's legs in stockings of different patterns, especially dots, Jadran's signature pattern. Jadran čarape target 
60

fashion-conscious women with their communications, sending the message that a woman can look beautiful, attractive and sexy in their stockings.

\section{Conclusion and discussion}

The objective of this paper was to define a matrix that could be used for the deconstruction and content analysis of commercial brands' Facebook campaigns.

\section{Hypotheses:}

H1: Brand promotion campaigns on Facebook are focused in two directions: communicating the quality and the characteristics of the brand to the target audience, and maximizing their reach and influence by being as viral as possible.

H2: An analysis of the form and content of Facebook posts can lead to conclusions about the target audience in the campaign and the messages it is trying to communicate.

It was proven on the example of three subjects whose FB profile communications we studied that the matrix containing 43 subcategories grouped in 12 categories for better visibility is sufficient for the analysis of commercial brands' FB campaigns. Considering that we studied consumer brands addressing a broad audience in this paper, we believe future research should focus on studying the applicability of the matrix to other brands, such as humanitarian, sports and culture associations and projects, state and local government and self-government institutions, and public companies. We are referring to the research and analysis of their communication with their stakeholders on Facebook. FB profiles that have more or fewer "friends" can be included in the selection of subjects and differences in the activity of their FB communities can be analysed. One of the questions, for example, can be if a FB community with fewer "friends" necessarily has a weaker engagement, or if some other elements are crucial for engagement (the cohesion power of the community, the passion and the emotional charge of the individuals engaged in communication, the strength of the messages communicated, etc).

The matrix can be further developed and upgraded in this sense. It is also possible to expand papers and focus on research whether a ISSN 1330-0067 qualitative analysis of FB campaign contents can offer indications of the extent to which this campaign is connected with campaigns in other (offline and online) media and whether the brand has a single communication strategy for all media.

Let us now return to our hypotheses.

H1: Through content analysis of FB posts using the matrix we presented here and its variables, we demonstrated that all three analysed brands are attempting to communicate their core characteristics and qualities through their communication on Facebook. They are also trying to maximize virality through the choice of the content they offer to their audience and through intensive activity of community managers (persons in charge of managing FB communications), using recognisable "tricks" to capture the attention of their audience and encourage their engagement (giveaways, discounts, direct invitations to use products/services, surveys etc), and to thus indirectly maximize their reach and impact. In this sense, we can conclude that Hypothesis 1 has been confirmed.

$\mathrm{H} 2$ : As far as our second hypothesis is concerned, we also believe that the content analysis of FB communications of all three analysed profiles was indicative of the audience that the brands address and the messages that they want to communicate.

Further research can focus on content analysis of the comments and replies to comments. Since our paper dealt with three commercial brands that have a dedicated audience, mostly positively oriented toward the brands, the comments are also predominantly positive or at least neutral (although it is possible that the absence of negative comments is due to the community manager deleting them). An analysis of the comments could show what types of contents generate positive, and what types of contents generate negative and even hateful comments, passionate comments whose basic idea is to insult, humiliate or intimidate. It is also possible to analyse the relationship between the number of comments and the number of likes, even though such analysis of numerical indicators is problematic in case of Facebook, because Facebook constantly changes algorithms and methods of calculation, as its entire strategy is focused on maximizing the number of paid posts.

Coden: IORME7 
Notes

/1/ Greenberger, M. (1971). Computers, Communications and the Public Interest. Baltimore: The Johns Hopkins University Press, 1971: 40.

/2/ Rose, F. (2015). The attention economy 3.0. FrankRose.com. pdf. 1406 2019: 44-45.

/3/ Berger, J. (2016). Contagion: why things catch on. Reprint. New York City: Simon \& Schuster, 2016: 23.a

/4/ Davenport, T.; Beck, C. J. (2001). The attention Economy: Understanding the New Currency of Business. Brighton, USA: Harvard Business School Press, p:20.

/5/ Ramsaran-Fowdar, Rooma Roshnee and Fowdar, Soora (2013). The Implications of Facebook Marketing for Organizations. //Contemporary Management Research 9,1, p. 73-84.

/6/ Bagozzi, Richard P. and Dholakia, Utpal M. (2006). Antecedents and Purchase Consequences of Customer Participation in Small Group Brand Communities.// International Journal of Research in Marketing 23, 1, p. 45-61.

/7/ Dholakia, Utpal. M., Durham, E. (2010). One Café Chain's Facebook Experiment.// Harvard Business Review 88, 3, p. 26.

/8/ Kang, J., Tang, L., Fiore, A. M. (2014). Enhancing consumer-brand relationships on restaurant Facebook fan pages: Maximizing consumer benefits and increasing active participation.// International Journal of Hospitality Management 36, p. 145155.

19/ Van Belleghem, S., Eenhuizen, M., Veris, E. (2014) Social Media Around the World 2011. InSites Consulting. Retrieved 04/07/2014 from http://www.slideshare.net/stevenvanbelleghem/social-media-around-the-world-2011\#

/10/ De Vries, L., Gensler, S., Leeflang, P.S.H. (2012). Popularity of Brand Posts on Brand Fan Pages: An Investigation of the Effects of Social Media Marketing.// Journal of Interactive Marketing 26, 2, p. 83-91.

/11/ Fortin D. R.; Dholakia R.R. (2005). Interactivity and vividness effects on social presence and involvement with a web-based advertisement // Journal of business research, 58, p. 387-396

Facebook Newsroom according to

http://www.theguardian.com/news/datab-

$\log / 2014 /$ feb/04/facebook-in-numbers-statistics, retrieved 04/07/2014.

Internet World Stats (www.internetworldstats.com), retrieved 04/07/2014.

/12/ Pletikosa Cvijikj, Irena and Michahelles, Florian. (2013). Online engagement factors on Facebook brand pages.// Social Network Analysis and Mining, 3, 4, p. 843-861.

/13/ Huang, R., Depari, G., Riorini, S., \& Wang, P. (2018). Leveraging Social Media Metrics in Improving Social Media Performances through Organic Reach: A Data Mining Approach, Review of Economic and Business Studies, 11(2), 33-48. doi: https://doi.org/10.1515/rebs-2018-0072.

/14/Luckerson, V. (2015). "Here's How Facebook's New Feed Actually Works." Time.com (blog). Accessed May 31, 2017. http://time.com/collection-post/3950525/facebook-news-feed-algorithm/.

/15/ Social@Ogilvy. (2014). March 6, “Facebook Zero: Considering Life After the Demise of Organic Reach." Accessed May 31, 2017. https://social.ogilvy.com/facebook-zero-considering-life-afterthe-demise-of-organic-reach/.

/16/ Kite J, Grunseit A, Li V, Vineburg J, Berton N, Bauman A, Freeman B. (2019). Generating Engagement on the Make Healthy Normal Campaign Facebook Page: Analysis of Facebook Analytics, JMIR Public Health Surveill 2019;5(1):e11132, DOI: $10.2196 / 11132$.

/17/ Read, A. (2016.) "Facebook Organic Reach is Dying: Here's Why It's A Good Thing." Unbounce.com (blog). Accessed May 31, 2017. https://unbounce.com/social-media/facebook-organic-reach-is-dying-heres-whyits-a-goodthing/.

/18/ Fulgoni, Gian M. (2016). "How Brands Using Social Media Ignite Marketing and Drive Groups, 80M On Fb Lite," http://techcrunch.com/2016/01/27/facebookgrows/.

/19/ Sprinklr. (2014). Everything you need to know about paid social. Retrieved from https:// facebookmarketingpartners.com/wp-content/uploads/2015/02/Whitepaper_Everything-YouNeed-to-Know-About-Paid-Social.pdf.

/20/ Constine, J. (2016), "Facebook Hits 100M Hours Of Video Watched A Day, 1B Users On

/21/Vamsi Kanuri, Yixing Chen, and Shrihari Sridhar, "Scheduling Content on Social Media: Theory, Evidence and Application," Journal of Marketing, 82 (November).

/22/ Kumar, A., Ram B., Rishika R., Ramkumar J., and Kannan P. K. (2016). “From Social to Sale: The Effects of Firm-Generated Content in Social Media on Customer Behavior," Journal of Marketing, 80 (1), 7-25.

/23/ Naylor, R., Walker, Cait Poynor Lamberton, West P. M. (2012). “Beyond The 'Like' Button: The Impact of Mere Virtual Presence on Brand E- 
62

valuations and Purchase Intentions in Social Media Settings," Journal of Marketing, 76 (6), 10520.

/24/ Boland, B. (2014). “Organic Reach on Facebook: Your Questions Answered," Facebook Business (June 5), https://www.facebook. com/business/news/Organic-Reach-on-Facebook.

/25/ Ballings M, et al. (2015). Social media optimization: Identifying an optimal strategy for increasing network size on Facebook. Omega (2015), http://dx.doi.org/10.1016/j.omega.2015.04.017i

/26/ Bernritter, S.F., Verlegh P.W.J., Smit E.G.. (2016). Why nonprofits are easier to endorse on social media: The roles of warmth and brand symbolism. Journal of Interactive Marketing 33 (February): $27-42$.

/27/ Zelm A. (2018) https://www.kunocreative.com/blog/facebook-reach-in-2018__ Facebook Reach in 2018: How Many Fans Actually See Your Posts?

/28/ Peterson, Ti. (2016). “Facebook makes Pages' organic reach in News Feed even more dependent on share." MarketingLand.com (blog). Accessed May 31, 2017. http://marketingland.com/facebook-makes-pages-organicreach-even-dependent-shares-182769

/29/ Cheung, Fanny Sau-Lan, and Leung, Wing-Fai. (2016.) “Facebook Users' Habits in Getting Commercial Information: A Study on Hong Kong Students," Economics, Management, and Financial Markets 11 (3): 56-71.

/30/ Malhotra, A., Kubowicz Malhtra C., See A. (2013). "How to Create Brand Engagement on Facebook." MIT Sloan Management Review 54 (2):18-20. Accessed May 31, 2017. Mar. 2017. DOI:10.2501/JAR-2015-004.

/31/ Carah, N. (2015). Algorithmic brands: A decade of brand experiments with mobile and social media. New Media and Society. doi:10.1177/1461444815605463.

/32/ Carah, N., \& Dobson, A. (2016). Algorithmic hotness: Young women's "promotion" and "reconnaissance" work via social media body images. Social Media + Society, 2, 1-10. doi:10.1177/2056305116672885.

/33/ Carah, N., Brodmerkel, S., \& Hernandez, L. (2014). Brands and sociality: Alcohol branding, drinking culture and Facebook. Convergence: International Journal of Research into New Media Technologies, 20, 259-275. doi:10.1177/1354856514531531

/34/ Nicholls, J. (2012). Everyday, everywhere: Alcohol marketing and social media - Current trends. Alcohol and Alcoholism, 47, 486-493. doi:10.1093/alcalc/ags043
Literature

1. Peruta A., Shields A. B. (2018): Marketing your university on social media: a content analysis of Facebook post types and formats, Journal of Marketing for Higher Education, DOI: 10.1080/08841241.2018.1442896

2. Carah N., Meurk C., Males M. \& Brown J. (2017): Emerging social media 'platform' approaches to alcohol marketing: a comparative analysis of the activity of the top 20 Australian alcohol brands on Facebook (2012-2014), Critical Public Health, DOI: 10.1080/09581596.2017.1282154.

3. Chaykowski, K. December 08, 2015. "Number Of Facebook Business Pages Climbs To 50 Million With New Messaging Tools." Forbes. Accessed May 31, 2017. https://www.forbes.com/sites/kathleenchaykowski/2015/12/08/ facebook-businesspages-climb-to-50-million-with-new-messagingtools/.

4. Hilde A. M. Voorveld, Theo Araujo, Stefan F. Bernritter, Edwin Rietberg \& Rens Vliegenthart (2018): How advertising in offline media drives reach of and engagement with brands on Facebook, International Journal of Advertising, DOI: 10.1080/02650487.2018.1454703.

5. Keith A. Quesenberry \& Michael K. Coolsen (2018): What Makes Facebook Brand Posts Engaging? A Content Analysis of Facebook Brand Post Text That Increases Shares, Likes, and Comments to Influence Organic Viral Reach, Journal of Current Issues \& Research in Advertising, DOI: 10.1080/10641734.2018.1503113.

6. Kirtiş, A.K. and Karahan, F., (2011). To be or not to be in social media arena as the most cost-efficient marketing strategy after the global recession. Procedia-Social and Behavioral Sciences, 24, pp. 260-268.

7. Mochon, D., Johnson, K., Schwartz, J. \& Ariely, D. (2017) "What are likes worth? A Facebook page field experiment," Journal of Marketing Research, 54(2), 306-317.

8. Smith, Kit. May 12, 2016. "Marketing: 47 Facebook Statistics for 2016." Brandwatch.com (blog). Accessed May 31, 2017. https://www.brandwatch.com/blog/47-facebookstatistics-2016/.

9. "What's the difference between, paid and total reach?". 2017. Facebook.com. Accessed May 31, $2017 . \quad$ https://www. facebook.com/help/285625061456389?helpref1/4uf_pe rmalink. 